\title{
Chronic Constipation: An Evidence-Based Review
}

\author{
Lawrence Leung, MBBChir, FRACGP, FRCGP, Taylor Riutta, MD, \\ Jyoti Kotecha, MPA, MRSC, and Walter Rosser MD, MRCGP, FCFP
}

Background: Chronic constipation is a common condition seen in family practice among the elderly and women. There is no consensus regarding its exact definition, and it may be interpreted differently by physicians and patients. Physicians prescribe various treatments, and patients often adopt different over-the-counter remedies. Chronic constipation is either caused by slow colonic transit or pelvic floor dysfunction, and treatment differs accordingly.

Methods: To update our knowledge of chronic constipation and its etiology and best-evidence treatment, information was synthesized from articles published in PubMed, EMBASE, and Cochrane Database of Systematic Reviews. Levels of evidence and recommendations were made according to the Strength of Recommendation taxonomy.

Results: The standard advice of increasing dietary fibers, fluids, and exercise for relieving chronic constipation will only benefit patients with true deficiency. Biofeedback works best for constipation caused by pelvic floor dysfunction. Pharmacological agents increase bulk or water content in the bowel lumen or aim to stimulate bowel movements. Novel classes of compounds have emerged for treating chronic constipation, with promising clinical trial data. Finally, the link between senna abuse and colon cancer remains unsupported.

Conclusions: Chronic constipation should be managed according to its etiology and guided by the best evidence-based treatment.(J Am Board Fam Med 2011;24:436-451.)

Keywords: Chronic Constipation, Clinical Review, Evidence-Based Medicine, Family Medicine, Gastrointestinal Problems, Systematic Review

The word "constipation" has varied meanings for different individuals. Although medical personnel define constipation as $<3$ bowel movements per week, ${ }^{1,2}$ patients often equate constipation with stool consistency, feelings of incomplete emptying, straining, and urge for defecation. ${ }^{3,4}$ Furthermore, the normalcy of bowel habit ranges widely from 3 bowel movements per day to 3 per week, ${ }^{5}$ with a tendency to underestimate while self-reporting ${ }^{6}$; hence, using defecation frequency alone may not be diagnostic of constipation. The Rome Foundation

This article was externally peer reviewed.

Submitted 13 November 2010; revised 20 February 2011; accepted 7 March 2011.

From the Department of Family Medicine (LL, TR, WR) and the Centre of Studies in Primary Care (LL, JK, WR), Queen's University, Kingston, Ontario, Canada.

Funding: none.

Conflict of interest: none declared.

Corresponding author: Lawrence Leung, Department of Family Medicine, Queen's University, 220 Bagot Street, Kingston, Ontario, Canada K7L 5E9 (E-mail: leungl@ queensu.ca). was established in 1991 by Drossman et al, primarily to standardize consensus-derived criteria of functional gastrointestinal disorder, and released the Rome III criteria in 2006 for constipation as having at least 2 of the following: (1) straining during $\geq 25 \%$ defecation; (2) lumpy or hard stools in $\geq 25 \%$ of defecation; (3) sensation of incomplete evacuation in $\geq 25 \%$ of defecation; (4) sensation of anorectal obstruction/blockage in $\geq 25 \%$ of defecation; (5) need for manual maneuvers to facilitate in $\geq 25 \%$ of defecation; and (6) fewer than 3 defecations per week. ${ }^{7,8}$ Also, patients should rarely have loose stools without laxatives and be distinct from having irritable bowel syndrome. ${ }^{8,9}$ For constipation to be defined as chronic, a patient must be symptomatic for at least 6 months with applicable criteria for the previous 3 months. ${ }^{3,9}$ Although the validity of the Rome III criteria for constipation has been recently questioned, ${ }^{10}$ with a known disparity between self-reported and criteria-based definitions, ${ }^{11}$ the use of colonic transit time ${ }^{12,13}$ and 
anorectal function tests ${ }^{14}$ as diagnostic tools is still controversial. In general, the prevalence of constipation among the general population in North America has been quoted as $1.9 \%$ to $27.2 \%,{ }^{15,16}$ with $50 \%$ to $74 \%$ of the institutionalized elderly reporting daily use of laxatives. ${ }^{17,18}$ Women are 2 to 3 times more likely to have constipation than men in terms of prevalence $e^{3,15,19-21}$ and physical symptoms. ${ }^{15,20}$ Possible reasons include higher risk of injury to the pelvic floor from childbirth ${ }^{22}$ and the general willingness of women to report their symptoms and respond to surveys. ${ }^{23}$ Advanced age is also a risk factor for chronic constipation, with the largest increase in prevalence after the age of 70 years. ${ }^{15}$ This can be due to effects of medication, immobility, and blunted urge to defecate. In the United States, constipation accounts for 7 million physician visits per year ${ }^{24}$ and is among the top 5 outpatient gastrointestinal diagnoses. ${ }^{25}$ Annually, diagnostic workup for constipation averages US\$3000 per patient, ${ }^{26}$ and it takes another US\$4500 per person to provide treatment. ${ }^{27}$ In general, constipation has a significant impact on quality-of-life indicators irrespective of culture and nationalities, ${ }^{28}$ especially on the elderly. ${ }^{29}$ A recent systematic review showed that impairment caused by constipation as measured by Health-Related Quality of Life scores predominates in the mental health domains and is comparable to that caused by serious chronic conditions such as osteoarthritis and diabetes. ${ }^{30}$

\section{Etiology of Chronic Constipation}

\section{Extrinsic Factors}

Low fiber intake, inadequate hydration, reduced mobility as the result of general functional decline and institutionalization, reduced sensation of thirst, electrolyte disturbances (hypercalcemia, hypokalemia, hypermagnesemia), endocrine and metabolic disorders (eg, diabetes mellitus, hyperparathyroidism, hypothyroidism, chronic renal failure), neurological disorders (eg, dementia, Parkinson disease, neuropathies, multiple sclerosis, spinal cord injuries, cauda equine syndrome), psychological comorbidities (eg, depression, distress, personality disorders, or history of abuse), and concurrent medications (eg, anticholinergics, diuretics, $\beta$-blockers, opiates, iron supplements, calcium channel blockers, antidepressants, acetaminophen, aspirin and NSAIDs) all are said to contribute to chronic constipation, especially in the elde- rly. ${ }^{17,31-36}$ Among them, the trio of insufficient dietary fiber, fluids, and exercise has been widely ascribed, ${ }^{37}$ but in fact the evidence behind these 3 factors is inconsistent and of low to medium quality. ${ }^{38}$ (See Notes section: Diagnostic Approach for Chronic Constipation.) The association between smoking, alcohol, and body mass index with chronic constipation L131(BMI) is inconclusive. ${ }^{36,39}$

\section{Intrinsic Factors}

Normal defecation requires a series of orchestrated actions, starting with relaxation of the puborectalis muscles, descent of the pelvic floor with straightening of the anorectal angle, inhibition of segmental colonic peristalsis, contraction of the abdominal wall muscles, and finally, relaxation of the external anal sphincter with expulsion of feces. Intrinsic factors leading to chronic constipation can be broadly classified into 2 categories: pelvic floor dysfunction (PFD) and slow colon transit time (STC). A retrospective study reported the prevalence of PFD as $37 \%$ and STC as $23 \%,{ }^{40}$ based on physiologic tests. However, a clear distinction between the two is often impossible, with an overlap of up to $55 \% .^{40,41}$

Anorectal/PFD involves laxity of the pelvic floor muscles, impaired rectal sensation, and decreased luminal pressure in the anal canal and have been documented as causes for chronic constipation in the elderly, especially in women. ${ }^{42-44}$ On the contrary, paradoxical contraction of the puborectalis and external anal sphincter during defecation can lead to incomplete emptying ${ }^{45,46}$ or even functional outlet obstruction. Finally, anatomic anomalies (such as rectal wall prolapse or rectocele) or perineal damage (from traumatic childbirth or sacral nerve injury) can also distort the normal functions of the anorectal/pelvic floor unit.

STC is a poorly understood condition thought to be a cause of intractable constipation in children $^{47}$ and young women. ${ }^{48}$ It is characterized by reduced high-amplitude propagated contractions $^{49,50}$ in the colon, leading to slow transit of feces, bloating, abdominal discomfort, and infrequent defecation. ${ }^{51}$ The protracted time in the colon also renders the feces hard and small and fails to mount sufficient rectal pressure to trigger the defecation reflex. ${ }^{52}$ Often, the pressure required is found to be higher than in subjects with normal colonic transit. ${ }^{53}$ Various physiologic and histobio- 
chemical findings have been postulated to explain the phenomenon of slow colonic transit: reduced cholinergic $^{54,55}$ and enhanced adrenergic respon$\mathrm{ses}^{55}$; mitigated gastrocolic reflex ${ }^{56}$; dysynergy of rectosigmoid colonic activities ${ }^{57,58}$; enteric neurodegeneration $^{59}$ of both the myenteric plexus ganglia $^{60,61}$ and the interstitial cells of Cajal ${ }^{61,62}$; and abnormalities of enteric neurotransmitters such as substance $\mathrm{P},{ }^{63-65}$ vasoactive intestinal peptides, ${ }^{63,64}$ and nitric oxide. ${ }^{63,66}$

\section{Complications of Chronic Constipation}

(1) Fecal incontinence: Overflow incontinence caused by fresh fecal matter bypassing the inssipated obstructing bolus ${ }^{67}$ may confuse the diagnosis of chronic constipation unless a rectal examination is performed. The odds ratio for developing fecal incontinence with chronic constipation is $1.7 .^{68}$

(2) Hemorrhoids: Prolonged straining and increase of intra-abdominal pressure raises the venous pressure in the plexus and ateriovenous anastomoses of the anorectal junction. ${ }^{69}$ The relative risk for development of hemorrhoids with constipation is up to $4.1 .^{70}$

(3) Anal fissure: Trauma and sudden tear of the anal mucosa during evacuation of hard stool is usually an initiating event, but spasm of the internal anal sphincter leading to relative ischemia is thought to be the perpetuating factor. ${ }^{69}$ It is estimated that anal fissure is 5 times more likely to develop with chronic constipation..$^{70,71}$

(4) Organ prolapse: Chronic constipation is a known risk for prolapse of pelvic organs such as the uterus, rectum, urinary bladder, and vagina ${ }^{72}$ and their recurrence. ${ }^{73}$ The odds ratio for having rectal prolapse is quoted as 2.3. ${ }^{68}$

(5) Fecal impaction and bowel obstruction: Prolonged stasis of fecal matter leads to impaction and giant fecolith obstructing the large bowel, necessitating surgery. ${ }^{74,75}$ Retrospective analysis revealed a 5- to 6-times increased risk of fecal impaction resulting from chronic constipation. ${ }^{68,70,71}$

(6) Bowel perforation and stercoral peritonitis: Extremely impacted feces (fecaloma) can compress the colonic wall, causing an ischemic ulcer ${ }^{76}$ and subsequent perforation, ${ }^{77,78}$ culminating in stercoral peritonitis ${ }^{78,79}$ and sometimes death. ${ }^{79}$ It is not a common condition; fewer than 90 cases have been reported in the medical literature from 1894 to $2006 .^{80}$

\section{Diagnostic Approach and Investigations}

It is important to conduct a detailed history and physical examination before proceeding with investigations. It is imperative to understand the patient's views and definitions of chronic constipation, which may often differ from medical criteria. The clinician should also weigh the costbenefits of investigations and only order those that help diagnose the etiology of chronic constipation and affect the treatment and prognosis in such patients. A brief outline of the diagnostic approach for chronic constipation is given in the Notes section: Diagnostic Approach for Chronic Constipation. It must be emphasized that these investigations are not indicated as routine studies except for differentiating between slow colon transit time and pelvic floor dysfunction, in which treatment would differ. Moreover, contrast studies and colonoscopy should be considered if the patient has a positive family history of colon cancer or inflammatory bowel disease and presents with alarming complaints of rectal bleeding, abrupt weight loss, anemia, or change in bowel habits.

\section{Evidence-Based Management of Chronic Constipation}

Methods

A literature search of published medical reports in all languages was performed from PUBMED, EMBASE, and the Cochrane Database of Systematic Reviews from inception to October 2010 using the OVID Portal of Queen's University, Kingston, Ontario. Abstracts were initially obtained using key words of "chronic constipation," "treatment," and "trials." Manual searches of references and review articles supplemented the computerized search, and only full-length articles were considered. Two reviewers (L.L. and T.R.) worked independently and went over the initial search for abstracts that satisfied the key words as mentioned. They then adopted a simple form to select studies that satisfied the following 2 inclusion criteria: (1) involving human subjects over the age of 18 years and (2) describing at least 1 form of treatment for chronic constipation. Evaluation of selected studies was performed by each reviewer (L.L. and T.R.) regarding their quality and evidence according to the Strength of Recommendations Taxonomy (SORT) ${ }^{81}$ with levels of evidence from I to III and recommendations from A to C. Any disagreement 
was discussed and resolved among the reviewers to reach mutual consensus.

\section{Results}

One hundred forty-five abstracts were identified by using key words of "chronic constipation" AND "treatment" AND "trials." Duplicates were removed, and, after imposing the selection criteria, only 62 relevant full-text articles were then retrieved for potential inclusion. ${ }^{9,34,46,82-141}$ They were deemed eligible on which mutual consensus was reached between the two reviewers (LL and TR). Additional consultation with the other two coauthors (WR and JK) was sought as required. The studies were then rated according to the SORT as below and summarized in the Notes section: Senna, Melanosis Coli, and Colon Cancer: Fact or Myth?

\section{Lifestyle Modifications}

Despite the fact that chronic constipation had been observed with deficiency in dietary fiber, fluids, or exercise, lifestyle modification to prevent or treat chronic constipation is still unsubstantiated. ${ }^{82,142}$ (See Notes section: Lack of Dietary Fiber, Fluid, and Exercises Will Cause Constipation: How True Is This?) However, such principles are widely disseminated to the public through pamphlets ${ }^{37}$ and practice guidelines (http://www.worldgastroenterology. org/assets/downloads/en/pdf/guidelines/05 constipation.pdf). Studies only report benefits if there is a lack of any of the three. Physicians and allied medical professionals should be aware of the evidence when advising their patients.

\section{Biofeedback}

For the PFD type of chronic constipation, biofeedback provides a retraining of the sensation and control of the anorectum and pelvic floor, thereby eliminating paradoxical contractions during the process of defecation. Its value has been shown both in uncontrolled trials ${ }^{93}$ and in recent randomized, controlled trials (RCTs) ${ }^{46,92,94}$ for improving both psychological and clinical outcome measures. There have been no reports of adverse effects for using biofeedback. As a result, the level of evidence and recommendation in using biofeedback for PFD type of chronic constipation is good except for the diversity of protocols and heterogeneity of trial designs.

\section{Pharmacological Treatment}

Medications for chronic constipation can be categorized into bulk-forming agents, stool softeners and emollients, osmotic agents, stimulants, chloride channel activators, $5-\mathrm{HT}_{4}$ receptor agonists, and guanylate cyclase-c receptor agonist.

\section{Bulk-Forming Agents}

Bulk-forming agents are fiber supplements that expand with water to increase bulk of the stool and enhance bowel movements. Commercially available preparations include psyllium (ispaghula husks), calcium polycarbophil, methycellulose, and bran. Adequate fluid intake is a must for bulkforming agents to work; lack of water enhances bloating and may paradoxically predispose to bowel obstruction. Among them, psyllium has superior efficacy in treating constipation, with at least 3 RCTs demonstrating benefits over placebo in improving colonic transit time and stool consistency. ${ }^{98-100}$ Two controlled trials reported the benefits of bran in reducing the use of laxatives in the elderly. ${ }^{102,103}$ In comparison, there is only 1 controlled trial for methylcellulose ${ }^{104}$ and a case series for polycarbophil ${ }^{105}$ supporting their clinical use. Bulk-forming agents are considered as first-line agents for chronic constipation, especially in patients with dietary fiber deficiency.

\section{Stool Softeners and Emollients}

Docusate sodium is a commonly prescribed stool softener that has a detergent effect. Although there is no known study comparing its stand-alone efficacy against placebo, one double-blind randomized trial found docusate to be inferior to psyllium in chronic constipation. ${ }^{98}$ Another systematic review did show a small effect of docusate in increasing stool frequency in the chronically ill, but overall quality of evidence was poor. Hence, the recommendation for use of docusate sodium is only moderate. Mineral oil is an emollient used for its lubricating effect on stool, but no placebo-controlled, randomized trial has been reported. Aspiration and lipoid pneumonia is a known risk of using mineral oil in children ${ }^{143}$ and the elderly. ${ }^{144}$ The level of evidence for use of mineral oil is hence moderate. Stool softeners are often prescribed when bulkforming agents do not work or are not preferred. 


\section{Osmotic Agents}

Agents such as polyethylene glycol (PEG), lactulose, sorbitol, and magnesium hydroxide adsorb and retain water as the result of their hyperosmolar nature and enhance stool passage. PEG has the best evidence of use, with at least 3 well-designed RCTs demonstrating significant benefits of PEG over placebo $^{106-108}$ in increasing stool frequency and softness. However, PEG can cause nausea, flatulence, and diarrhea, especially in the elderly, and the dosage should be titrated upward according to response. ${ }^{19}$ In fact, some studies also reported efficacy at a low dosage of PEG. ${ }^{14-147}$ For lactulose, at least 2 systematic reviews reported RCTs showing efficacy over placebo, ${ }^{109,110}$ and the evidence is considered superior. No randomized, placebo-controlled trials have been conducted with sorbitol, but at least 1 double-blind, randomized, crossover study showed no difference in efficacy when compared with lactulose. ${ }^{111}$ Similarly, the use of magnesium hydroxide for chronic constipation is not supported by any placebo-controlled trials, with only 1 report of severe hypermagnesia requiring hemodialysis after chronic use. ${ }^{112}$ Osmotic agents are useful when first-line bulk-forming agents or stool softeners do not work.

\section{Stimulants}

Senna and bisacodyl are the most commonly used stimulants. They act on the myenteric plexus of the colon and stimulate peristaltic contractions, ${ }^{148,149}$ which decreases transit time. ${ }^{150,151}$ They also decrease water absorption from the lumen. For bisacodyl, there is a double-blind, randomized, placebo-controlled trial showing efficacy and safety over placebo ${ }^{114}$ and another open-labeled, randomized study showing comparable benefits with sodium picosulphate. ${ }^{113}$ The level and recommendation for using bisacodyl is superior. Surprisingly, despite the widespread use of senna for more than a century, there is no well-designed RCT comparing its efficacy with placebo. However, at least 3 controlled trials compared the effects of senna with another laxative in treating chronic constipation. It was found that senna was a better choice, ${ }^{115}$ or, senna enhanced the effects when given in combination. ${ }^{116,117}$ Even so, the recommendation for senna is only considered moderate. There has been intense debate as to the potential risk of colonic carcinoma as the result long-term use of senna, based on the observation that senna use leads to Melanosis coli, an alleged risk for cancer of the colon. (See Notes section: Senna, Melanosis Coli, and Colon Cancer: Fact or Myth?)

\section{Chloride Channel Activators}

Chloride channel activators are bicyclic fatty acids that increase intestinal fluid secretion by selectively activating type 2 chloride channels (CIC-2) in the apical membrane of the gastrointestinal epithelium. Lubiprostone is a representative that was licensed in $2004^{152}$ and approved in $2006^{153}$ by the Food and Drug Administration (FDA) for long-term treatment of chronic constipation. At least 3 double blind, randomized, placebo-controlled trials ${ }^{118-120}$ have shown efficacy of lubiprostone in increasing spontaneous bowel movements and improving selfreported symptoms of chronic constipation. Known adverse effects include headache, nausea, and diarrhea but are well tolerated. Long-term use of lubiprostone also appears to be safe. ${ }^{154}$ Evidence and recommendation for use of lubiprostone is hence excellent.

\section{5-Hydroxytryptamine Receptor Subtype 4 Agonists}

5-Hydroxytryptamine receptor subtype 4 (5- $\left.\mathrm{HT}_{4}\right)$ receptors are found in the primary afferent neurons, smooth muscle cells, enterochromaffin cells, and the myenteric plexus of the colon. ${ }^{155}$ They mediate the release of other neurotransmitters that initiate peristaltic action in the bowel. ${ }^{155,156}$ Tegaserod, a $5-\mathrm{HT}_{4}$ partial agonist, was approved by the FDA for use in 2002 both for constipation the dominant type of irritable bowel syndrome and also for idiopathic constipation in patients under the age of 65 years. Despite its efficacy shown by multiple randomized, placebo-controlled, clinical trials from different countries, ${ }^{121-124}$ the FDA disapproved marketing of tegaserod in 2007 because of a small increased risk in cardiovascular events, which led to its final withdrawal in 2008. This led to public criticisms against the FDA for being paternalistic and counterproductive. ${ }^{125,126}$ Research interest in tegaserod still continues, ${ }^{127}$ and 2 recent cohort studies have specifically shown a lack of association of cardiovascular events with tegaserod. ${ }^{128,129}$ Whether tegaserod will be relaunched in the future remains to be seen. Prucalopride is a highly selective $5-\mathrm{HT}_{4}$ agonist stimulating prokinetic activity of the colon in in vitro and in vivo studies of humans and animals. ${ }^{157}$ Clinically, it sig- 
nificantly improved bowel movements and other reported symptoms in patients with chronic constipation, ${ }^{130}$ especially in severe cases, ${ }^{131-134}$ with no significant cardiovascular adverse events. ${ }^{135}$ The level of evidence and recommendation for using prucalopride to treat chronic constipation is therefore superior, but it is only available in the European market.

\section{Guanylate Cyclase-c Receptor Agonist}

Linaclotide is a 14-amino acid peptide that acts on guanylate cyclase-c receptors of the colonic epithelium and induces intestinal fluid secretion and reduces colonic transit time. Its clinical efficacy and safety have been tested in randomized, doubleblind, placebo-controlled trials, ${ }^{158,159}$ with promising results thus far. Recommendation and level of evidence for prucalotide will not be forthcoming because of its experimental nature.

\section{Other Treatments}

Bacteriotherapy (Probiotics)

Lactobacillus and Bifidobacterium are recognized symbiotic flora in the large intestine that compete with harmful pathogens in binding to the surface of enterocytes and confer mucosal health. Both flora had been reported at low levels in patients with chronic constipation, ${ }^{160}$ which supports the use of these probiotic bacteria for treating chronic constipation and other inflammatory bowel conditions. ${ }^{161}$ One prospective study showed that Bifidobacterium supplementation can relieve constipation in hypocaloric dieting, ${ }^{95}$ whereas another prospective trial reported efficacy of Lactobacillus in improving chronic constipation in nursing home residents. ${ }^{96}$ However, survival and viability of these probiotic bacteria as consumed in commercial form has yet to be standardized for such treatment to be officially endorsed. ${ }^{97}$ Because of the lack of properly controlled trials, evidence and recommendation is poor.

\section{Traditional Chinese Medicine}

Chronic constipation was described in the ancient texts of Chinese medicine in $200 \mathrm{AD}$. It is treated by a combination of herbs and acupuncture, depending on the symptomatology. At least 2 RCTs have shown efficacy of a particular formula (YunChang capsule; aka Hemp Seed Pill) in treating the functional type of chronic constipation. ${ }^{36,137}$ However, the overall quality of studies using tradi- tional Chinese medicine for chronic constipation is heterogenous. ${ }^{138}$

\section{Surgery}

Patients with intractable chronic constipation caused by slow colon transit who fail pharmacological treatments may be considered for surgery. Possible operations include total colectomy or partial colectomy. A recent systematic review based on case reports and case series concluded that such surgical operations can improve defecatory frequencies and decrease postoperative use of laxatives; however, there is heterogeneity in design among the studies, resulting in variable quality of evidence. ${ }^{139}$ For the anismus type of PFD, at least 2 RCTs have shown benefits of partial division of puborectalis as compared with biofeedback ${ }^{140}$ or Botulinum toxin injection. ${ }^{140,141}$

\section{Conclusions}

It is indeed surprising that as a common condition found in at least one quarter of patients, chronic constipation is treated in a wide variety of ways, with relatively little evidence-based data, especially regarding dietary fiber, fluids and exercise. As with any other condition, a thorough history and physical examination is mandatory, with additional blood and special tests to confirm the diagnosis of chronic constipation and its subtypes. A practical triage approach is summarized in Figure 1), and the various evidence-based options for managing chronic constipation are listed in the order of their level of recommendation in Table 1 . In summary, family physicians should look for pelvic floor dysfunction as a cause of chronic constipation, which is best treated by biofeedback. The classic triad of increasing dietary fiber, exercise, and fluids will benefit patients with actual deficiencies. The best pharmacological treatment for chronic constipation caused by slow colonic transit time is to start with a bulk-forming agent (psyllium or bran) and with a stool softener/osmotic agent (lactulose, PEG, or docusate), then add in stimulants (bisacodyl or senna) and finally the newer agents for severe or resistant cases (chloride channel activators or $5-\mathrm{HT}_{4}$ agonist). In recalcitrant cases, surgical treatment may be considered. 
Figure 1. Flow diagram for management of chronic constipation.

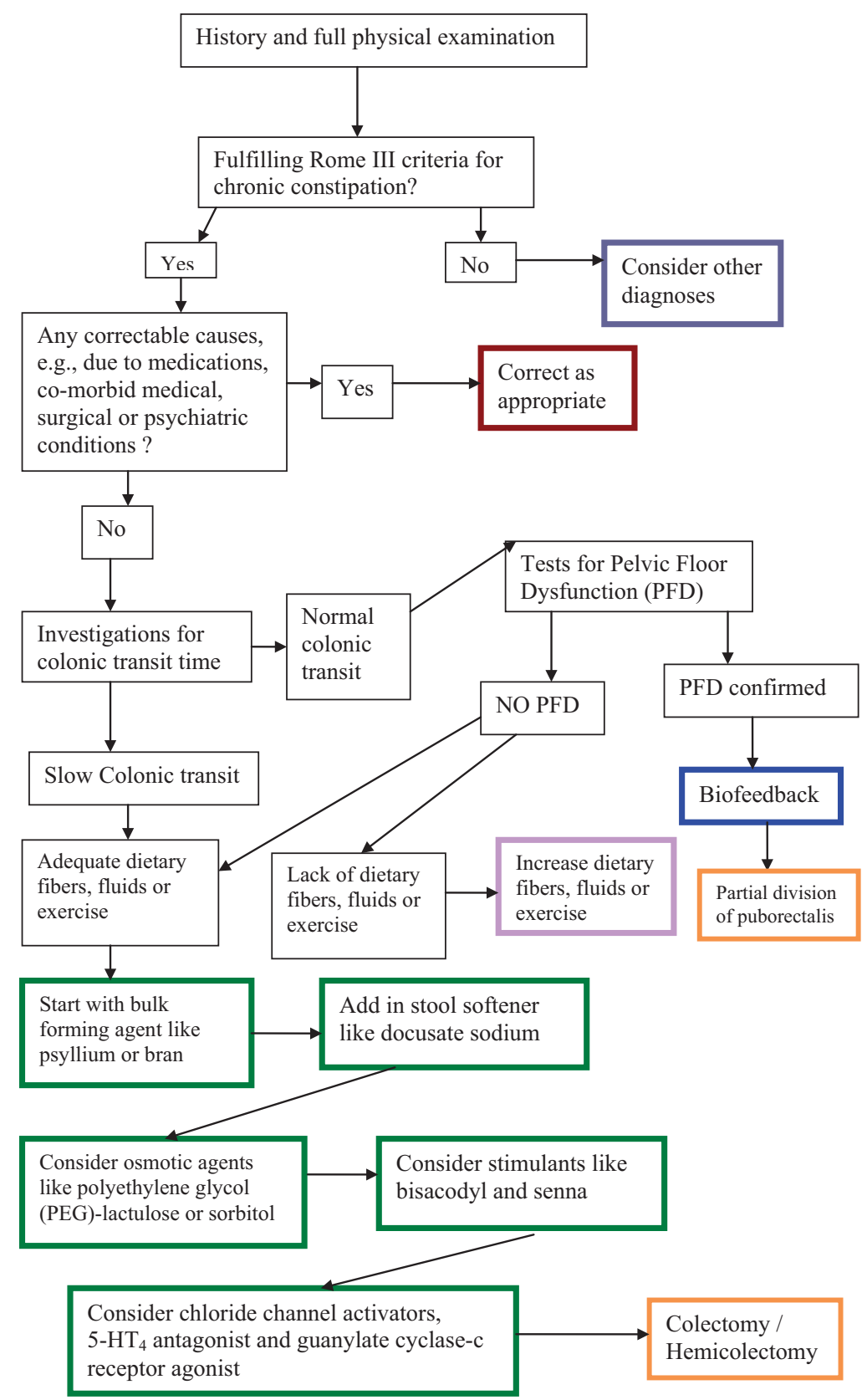

\section{Notes}

\section{Diagnostic Approach for Chronic Constipation}

History includes (1) duration of complaint; (2) patient's definition of constipation; (3) defecatory frequency; (4) stool consistency; (5) concurrent medication (eg, anticholinergics, diuretics, $\beta$-blockers, opiates, iron supplements, calcium channel blockers, antidepressants, acetaminophen, aspirin, and NSAIDs); (6) comorbidities (Parkinson, hypothyroidism); (7) use of supplements or laxatives; and (8) lifestyle enquiry regarding the level of fluid intake, dietary fiber consumption, and daily exercise.

Physical examination includes (1) previous surgical scars; (2) abdominal distension and bowel sounds; (3) palpable mass (fecoliths); (4) inspection of anus for skin tags, hemorrhoids, fissures, hematomas, and prolapse; (5) rectal examination to assess anal reflex, sphincter tone, tenderness, out-pouching (rectocele), or mass in the rectum; (6) gynecological examination to exclude cystoceles or vagi- 
Table 1. Summary of Various Management Options for Chronic Constipation According to the Strength of Recommendations Taxonomy $(\text { SORT })^{81}$

\begin{tabular}{|c|c|c|c|}
\hline Treatment & $\begin{array}{c}\text { Level of } \\
\text { Recommendation }\end{array}$ & Comments & Reference \\
\hline \multicolumn{4}{|l|}{ Nonpharmacological } \\
\hline Increasing dietary fiber & $\mathrm{C}$ & $\begin{array}{l}\text { No RCTs, data from multiple observational studies, results } \\
\text { conflicting. More likely to be beneficial in people with } \\
\text { fibers deficiency. }\end{array}$ & $34,82-87$ \\
\hline Increasing exercise & B & $\begin{array}{l}\text { Two small RCTs with opposite results and } 2 \text { other cohorts } \\
\text { showing benefits. More likely to be beneficial in people } \\
\text { with lack of exercise. }\end{array}$ & $9,83,88,89$ \\
\hline Increasing fluids & $\mathrm{C}$ & $\begin{array}{l}\text { One observational study and } 1 \text { controlled trial, the latter } \\
\text { showing benefits of increased fluids only in presence of } \\
\text { sufficient fiber intake. }\end{array}$ & 90,91 \\
\hline Biofeedback & B & $\begin{array}{l}\text { Useful in pelvic function disorder type of chronic } \\
\text { constipation. Benefits reported with both uncontrolled } \\
\text { trials and RCTs. However, protocols of biofeedback } \\
\text { vary and are heterogeneous in nature; hence } \\
\text { recommendation is not standardized. }\end{array}$ & $46,92-94$ \\
\hline Bacteriotherapy (probiotics) & $\mathrm{C}$ & $\begin{array}{l}\text { One prospective study of bifidobacterium and one } \\
\text { uncontrolled trial of Lactobacillus; viability of preparation } \\
\text { when consumed is questionable. }\end{array}$ & $95-97$ \\
\hline $\begin{array}{l}\text { Surgery (colectomy/ } \\
\text { hemicolectomy) }\end{array}$ & B & $\begin{array}{l}\text { One systematic review reported benefits based on case } \\
\text { reports and no RCT; quality of studies was } \\
\text { heterogeneous. }\end{array}$ & 139 \\
\hline $\begin{array}{l}\text { Surgery (partial division of } \\
\text { puborectalis) }\end{array}$ & B & $\begin{array}{l}\text { Two RCTs randomizing patients to surgical and } \\
\text { nonsurgical treatments (biofeedback or Botulinum toxin } \\
\text { injection). }\end{array}$ & 140,141 \\
\hline \multicolumn{4}{|l|}{ Pharmacological } \\
\hline Psyllium & A & $\begin{array}{l}\text { At least } 3 \text { well-designed RCTs showing benefits over } \\
\text { placebo. }\end{array}$ & $98-101$ \\
\hline Bran & $\mathrm{B}$ & $\begin{array}{l}\text { Two controlled trials showed benefits in reducing use of } \\
\text { laxatives. }\end{array}$ & 102,103 \\
\hline Methylcellulose & B & Only 1 controlled trial of medium quality. & 104 \\
\hline Polycarbophil & B & Only 1 case series of medium quality. & 105 \\
\hline Polyethylene glycol & A & At least 3 RCTs showing benefits over placebo. & $106-108$ \\
\hline Lactulose & A & $\begin{array}{l}\text { Two systematic reviews of RCTs with benefits over } \\
\text { placebos. }\end{array}$ & 109,110 \\
\hline Sorbitol & $\mathrm{B}$ & $\begin{array}{l}\text { One double-blind RCT showing comparable efficacy of } \\
\text { sorbitol with lactulose, not placebo. }\end{array}$ & 111 \\
\hline $\begin{array}{l}\text { Magnesium hydroxide (milk of } \\
\text { magnesia) }\end{array}$ & $\mathrm{C}$ & $\begin{array}{l}\text { No evidence of benefits from any studies, with } 1 \text { adverse } \\
\text { report of overuse. }\end{array}$ & 112 \\
\hline Senna & A & At least 3 controlled trials showing benefits over placebo. & $115-117$ \\
\hline Docusate sodium & B & One double-blind RCT comparing with psyllium. & 98 \\
\hline Bisacodyl & A & $\begin{array}{l}\text { One double-blind RCT with } 1 \text { open-labelled controlled } \\
\text { trial. }\end{array}$ & 113,114 \\
\hline Lubiprostone & A & $\begin{array}{l}\text { At least } 3 \text { double-blind RCTs showing benefits over } \\
\text { placebo. }\end{array}$ & $118-120$ \\
\hline Tegaserod & - & $\begin{array}{l}\text { At least } 3 \text { RCTs from different centers showed benefits } \\
\text { over placebo. Withdrawn from market by FDA because } \\
\text { of concern; } 2 \text { recent cohorts claim no association with } \\
\text { cardiovascular risks. }\end{array}$ & $121-129$ \\
\hline Prucalopride & A & $\begin{array}{l}\text { At least } 3 \text { RCTs showing benefits over placebo, including } \\
\text { severe chronic constipation. At present only marketed in } \\
\text { Europe. }\end{array}$ & $130-135$ \\
\hline Traditional Chinese medicine & B & $\begin{array}{l}\text { Two RCTs showing benefits of a particular formula, yet } \\
\text { overall quality of studies are heterogeneous. }\end{array}$ & $136-138$ \\
\hline
\end{tabular}

RCT indicates randomized, controlled trial; FDA, Food and Drug Administration. 
nal/uterine prolapse; and (7) full neurological examination to exclude neurological causes.

Investigations include (1) blood tests such as complete blood count, serum glucose, and thyroid and renal functions maybe useful despite limited evidence. ${ }^{162,163}$ (2) Colon transit time: Radiograph study with the Sitz marker has been a standard test in distinguishing prolonged transit from normal transit but is unreliable in measuring segmental transit. ${ }^{164}$ Scintigraphy with radioisotope is more accurate in measuring transit in different segments of the colon ${ }^{165}$ but is more expensive and limited to centers with access to radioisotopes. (3) Anorectal manometry: Pressure exerted by the anal sphincter at rest (normal $>80 \mathrm{~mm} \mathrm{Hg}$ ) and with defecatory attempt (normal $>180 \mathrm{~mm} \mathrm{Hg}$ ) is measured with a balloon catheter in the anal canal. ${ }^{166}$ (4) Balloon expulsion test: Patient is asked to expel a $50 \mathrm{~mL}$ rectal balloon (filled with air or water) within 60 seconds; failure to do so suggests pelvic floor dysfunction. ${ }^{14}$ (5) Defecography: Serial radiographs of the anorectum are taken when the patient is asked to expel thick barium paste from the rectum. Movement of the pelvic floor and anorectal angle is measured with reference to the sacro-coccygeal line. ${ }^{14}$ (6) Dynamic pelvic MRI gives better visualization of the pelvic floor dynamics than does conventional barium defecography and also reveals other anatomic defects contributing to impaired defecation. ${ }^{167}$

\section{Lack of Dietary Fiber, Fluid, and Exercises Will Cause Constipation: How True Is This? \\ Dietary Fiber}

A prospective cohort of 3327 women found that higher daily fiber intake $(20 \mathrm{~g} / \mathrm{d}$ versus $7 \mathrm{~g} / \mathrm{d})$ significantly reduces the likelihood of self-reported constipation. ${ }^{83}$ However, other studies have found no such association. ${ }^{34,84,85}$ Increasing daily dietary fiber intake may help constipation caused by fiber deficiency, ${ }^{34,84,86}$ but one should not assume that fiber deficiency is the main or sole cause. ${ }^{82,87}$ Evidence is Level 2C.

\section{Exercise}

One small, nonplacebo RCT reported that regular exercise decreases constipation as per Rome I criteria, ${ }^{88}$ whereas another even smaller study did not show any benefit. ${ }^{89}$ Two other cohort studies showed that physical activity significantly decreased the self-reported symptoms in women. ${ }^{9,83}$ Evidence is Level 2C.

\section{Fluids}

A 3-month, prospective study of 21012 nursing home residents age $>65$ years found a link between insufficient fluid intake and constipation. ${ }^{90}$ One controlled trial showed that higher fluid intake improved chronic constipation in the presence of a high-fiber diet. ${ }^{91}$ Other than that there have been no known trials looking at the effects of increased fluids on chronic constipation. Evidence is hence $2 \mathrm{C}$.

\section{Senna, Melanosis Coli, and Colon Cancer: Fact or Myth?}

Senna belongs to the genera of anthroquinonecontaining herbal laxatives that also embrace aloe, cascara, frangula, and rhubarb. The active ingredients include sennoside A and B. Melanosis coli is a brownish-black discoloration of the colonic epithelium found with chronic use of anthraquinone laxatives, ${ }^{168}$ with an association of $73 \%$ to $95 \% .{ }^{147,169}$ Histologically, there is accumulation of lipofuscincontaining macrophages in the lamina propria of the colonic mucosa. ${ }^{170}$ Lipofuscin is thought to derive from apoptotic bodies generated by anthroquinone-induced apoptosis of the colonic epithelial cells. ${ }^{168,171}$ Melanosis coli can resolve after discontinuation of anthraquinone laxatives. ${ }^{169}$ In the last three decades, induction of aberrant crypt foci (ACF) in rat colon has been widely accepted as the pre-neoplastic lesions for modeling colorectal cancer. ${ }^{172-177}$ Although 2 studies showed that senna promoted formation of carcinogen-induced ACF in rat colon when given at high doses, ${ }^{178,179}$ other studies failed to show any effects of senna in initiating ACF per se or promoting existing ACF. ${ }^{180,181}$ In fact, one study even demonstrated a reduction of ACF in rat colon after long-term usage of senna. ${ }^{182}$ Similar data in humans are lacking, except for one study that showed increased ACF after a single high dose of senna colonic lavage. ${ }^{183}$ A prospective study of 1095 patients reported an increased relative risk of 3.04 for colorectal cancer as a result of anthraquinone laxative abuse. ${ }^{184}$ Similarly, a retrospective study of 3049 patients who underwent colonoscopy revealed a higher incidence of Melanosis coli in patients diagnosed with colonic adenomas ${ }^{184}$ (which are not necessarily malignant). However, subsequent studies failed to demonstrate an association of anthraquinone laxatives 
with colorectal carcinomas. ${ }^{180,185-188}$ Interestingly, one study even hypothesized that the higher rate of adenomas associated with Melanosis coli was due to enhanced ease to spot the white polyps against a dark-colored colon. ${ }^{189}$ Taken together, the latest evidence does not support a role of senna in causing colon cancer in rats and humans. ${ }^{190}$

\section{References}

1. Drossman DA, Sandler RS, McKee DC, Lovitz AJ. Bowel patterns among subjects not seeking health care: use of a questionnaire to identify a population with bowel dysfunction. Gastroenterology 1982;83: 529-34.

2. Connell AM, Hilton C, Irvine G, Lennard-Jones JE, Misiewicz JJ. Variation of bowel habit in two population samples. Br Med J 1965;2:1095-9.

3. Pare P, Ferrazzi S, Thompson WG, Irvine EJ, Rance L. An epidemiological survey of constipation in canada: definitions, rates, demographics, and predictors of health care seeking. Am J Gastroenterol 2001;96:3130-7.

4. Heaton KW, Radvan J, Cripps H, Mountford RA, Braddon FE, Hughes AO. Defecation frequency and timing, and stool form in the general population: a prospective study. Gut 1992;33:818-24.

5. Herz MJ, Kahan E, Zalevski S, Aframian R, Kuznitz D, Reichman S. Constipation: a different entity for patients and doctors. Fam Pract 1996;13: 156-9.

6. Ashraf W, Park F, Lof J, Quigley EM. An examination of the reliability of reported stool frequency in the diagnosis of idiopathic constipation. Am J Gastroenterol 1996;91:26-32.

7. Drossman DA. Rome III: the new criteria. Chin J Dig Dis 2006;7:181-5.

8. Longstreth GF, Thompson WG, Chey WD, Houghton LA, Mearin F, Spiller RC. Functional bowel disorders. Gastroenterology 2006;130:1480-91.

9. Brown WJ, Mishra G, Lee C, Bauman A. Leisure time physical activity in Australian women: relationship with well being and symptoms. Res Q Exerc Sport 2000;71:206-16.

10. Digesu GA, Panayi D, Kundi N, Tekkis P, Fernando R, Khullar V. Validity of the Rome III criteria in assessing constipation in women. Int Urogynecol J Pelvic Floor Dysfunct 2010 Oct;21(10): 1185-93.

11. Garrigues V, Galvez C, Ortiz V, Ponce M, Nos P, Ponce J. Prevalence of constipation: agreement among several criteria and evaluation of the diagnostic accuracy of qualifying symptoms and selfreported definition in a population-based survey in Spain. Am J Epidemiol 2004;159:520-6.

12. Cowlam S, Khan U, Mackie A, Varma JS, Yiannankou Y. Validity of segmental transit studies used in routine clinical practice, to characterize defaecatory disorder in patients with functional constipation. Colorectal Dis 2008;10:818-22.

13. Manabe N, Wong BS, Camilleri M, Burton D, McKinzie S, Zinsmeister AR. Lower functional gastrointestinal disorders: evidence of abnormal colonic transit in a 287 patient cohort. Neurogastroenterol Motil 2010 Mar;22(3):293-e82.

14. Bharucha AE. Update of tests of colon and rectal structure and function. J Clin Gastroenterol 2006; 40:96-103.

15. McCrea GL, Miaskowski C, Stotts NA, Macera L, Varma MG. A review of the literature on gender and age differences in the prevalence and characteristics of constipation in North America. J Pain Symptom Manage 2009;37:737-45.

16. Higgins PD, Johanson JF. Epidemiology of constipation in North America: a systematic review. Am J Gastroenterol 2004;99:750-9.

17. Bouras EP, Tangalos EG. Chronic constipation in the elderly. Gastroenterol Clin North Am 2009;38: 463-80.

18. Hosia-Randell H, Suominen M, Muurinen S, Pitkala KH. Use of laxatives among older nursing home residents in Helsinki, Finland. Drugs Aging 2007;24:147-54.

19. Brandt LJ, Prather CM, Quigley EM, Schiller LR, Schoenfeld P, Talley NJ. Systematic review on the management of chronic constipation in North America. Am J Gastroenterol 2005;100(Suppl 1): S5-21.

20. McCrea GL, Miaskowski C, Stotts NA, Macera L, Paul SM, Varma MG. Gender differences in selfreported constipation characteristics, symptoms, and bowel and dietary habits among patients attending a specialty clinic for constipation. Gend Med 2009;6:259-71.

21. Choung RS, Locke GR 3rd, Schleck CD, Zinsmeister AR, Talley NJ. Cumulative incidence of chronic constipation: a population-based study 1988-2003. Aliment Pharmacol Ther 2007;26:1521-8.

22. Kepenekci I, Keskinkilic B, Akinsu F, et al. Prevalence of pelvic floor disorders in the female population and the impact of age, mode of delivery, and parity. Dis Colon Rectum 2011;54:85-94.

23. van Wijk CM, Kolk AM. Sex differences in physical symptoms: the contribution of symptom perception theory. Soc Sci Medicine 1997;45:231-46.

24. Shah ND, Chitkara DK, Locke GR, Meek PD, Talley NJ. Ambulatory care for constipation in the United States, 1993-2004. Am J Gastroenterol 2008;103:1746-53.

25. Shaheen NJ, Hansen RA, Morgan DR, et al. The burden of gastrointestinal and liver diseases, 2006. Am J Gastroenterol 2006;101:2128-38.

26. Rantis PC Jr, Vernava AM 3rd, Daniel GL, Longo WE. Chronic constipation: is the work-up worth the cost? Dis Colon Rectum 1997;40:280-6. 
27. Nyrop KA, Palsson OS, Levy RL, et al. Costs of health care for irritable bowel syndrome, chronic constipation, functional diarrhoea and functional abdominal pain. Aliment Pharmacol Ther 2007;26: 237-48.

28. Wald A, Scarpignato C, Kamm MA, et al. The burden of constipation on quality of life: results of a multinational survey. Aliment Pharmacol Ther 2007;26:227-36.

29. O'Keefe EA, Talley NJ, Zinsmeister AR, Jacobsen SJ. Bowel disorders impair functional status and quality of life in the elderly: a population-based study. J Gerontol A Biol Sci Med Sci 1995;50: M184-9.

30. Belsey J, Greenfield S, Candy D, Geraint M. Systematic review: impact of constipation on quality of life in adults and children. Aliment Pharmacol Therapeutics 2010;31:938-49.

31. Leroi AM, Bernier C, Watier A, et al. Prevalence of sexual abuse among patients with functional disorders of the lower gastrointestinal tract. Int J Colorectal Dis 1995;10:200-6.

32. Petticrew M, Rodgers M, Booth A. Effectiveness of laxatives in adults. Qual Health Care 2001;10:268-73.

33. Campbell AJ, Busby WJ, Horwath CC. Factors associated with constipation in a community based sample of people aged 70 years and over. J Epidemiol Community Health 1993;47:23-6.

34. Towers AL, Burgio KL, Locher JL, Merkel IS, Safaeian M, Wald A. Constipation in the elderly: influence of dietary, psychological, and physiological factors. J Am Geriatr Soc 1994;42:701-6.

35. Nehra V, Bruce BK, Rath-Harvey DM, Pemberton JH, Camilleri M. Psychological disorders in patients with evacuation disorders and constipation in a tertiary practice. Am J Gastroenterol 2000;95: 1755-8.

36. Chang JY, Locke GR, Schleck CD, Zinsmeister AR, Talley NJ. Risk factors for chronic constipation and a possible role of analgesics. Neurogastroenterol Motil 2007;19:905-11.

37. Patient handout. Does constipation ruin your day? What you eat, drink, and do can make a difference. Geriatrics 2005;60:19.

38. Frizelle F, Barclay M. Constipation in adults. Clin Evid (Online) 2007.

39. Pourhoseingholi MA, Kaboli SA, Pourhoseingholi A, et al. Obesity and functional constipation; a community-based study in Iran. J Gastrointest Liver Dis 2009; 18:151-5.

40. Surrenti E, Rath DM, Pemberton JH, Camilleri M. Audit of constipation in a tertiary referral gastroenterology practice. Am J Gastroenterol 1995;90:1471-5.

41. Prather CM. Subtypes of constipation: sorting out the confusion. Rev Gastroenterol Disord 2004; 4(Suppl 2):S11-6.

42. Bannister JJ, Abouzekry L, Read NW. Effect of aging on anorectal function. Gut 1987;28:353-7.
43. Laurberg S, Swash M. Effects of aging on the anorectal sphincters and their innervation. Dis Colon Rectum 1989;32:737-42.

44. Akervall S, Nordgren S, Fasth S, Oresland T, Pettersson K, Hulten L. The effects of age, gender, and parity on rectoanal functions in adults. Scand J Gastroenterol 1990;25:1247-56.

45. Rao SS, Welcher KD, Leistikow JS. Obstructive defecation: a failure of rectoanal coordination. Am J Gastroenterol 1998;93:1042-50.

46. Rao SS. Constipation: evaluation and treatment of colonic and anorectal motility disorders. Gastrointest Endosc Clin N Am 2009;19:117-39.

47. Hutson JM, McNamara J, Gibb S, Shin YM. Slow transit constipation in children. J Paediatr Child Health 2001;37:426-30.

48. Preston DM, Lennard-Jones JE. Severe chronic constipation of young women: 'idiopathic slow transit constipation.' Gut 1986;27:41-8.

49. Herve S, Savoye G, Behbahani A, Leroi AM, Denis $\mathrm{P}$, Ducrotte P. Results of 24-h manometric recording of colonic motor activity with endoluminal instillation of bisacodyl in patients with severe chronic slow transit constipation. Neurogastroenterol Motil 2004;16:397-402.

50. Bassotti G, Gaburri M, Imbimbo BP, et al. Colonic mass movements in idiopathic chronic constipation. Gut 1988;29:1173-9.

51. Stivland T, Camilleri M, Vassallo M, et al. Scintigraphic measurement of regional gut transit in idiopathic constipation. Gastroenterology 1991;101:107-15.

52. Bannister JJ, Davison P, Timms JM, Gibbons C, Read NW. Effect of stool size and consistency on defecation. Gut 1987;28:1246-50.

53. Lanfranchi GA, Bazzocchi G, Brignola C, Campieri M, Labo G. Different patterns of intestinal transit time and anorectal motility in painful and painless chronic constipation. Gut 1984;25:1352-7.

54. Bassotti G, Chiarioni G, Imbimbo BP, et al. Impaired colonic motor response to cholinergic stimulation in patients with severe chronic idiopathic (slow transit type) constipation. Dig Dis Sci 1993; 38:1040-5.

55. Tomita R, Tanjoh K, Fujisaki S, Ikeda T, Fukuzawa $M$. Regulation of the enteric nervous system in the colon of patients with slow transit constipation. Hepatogastroenterology 2002;49:1540-4.

56. Hagiwara N, Tomita R. Pathophysiology of chronic constipation of the slow transit type from the aspect of the type of rectal movements. Hepatogastroenterology 2008;55:1298-303.

57. Bassotti G, de Roberto G, Castellani D, Sediari L, Morelli A. Normal aspects of colorectal motility and abnormalities in slow transit constipation. World J Gastroenterol 2005;11:2691-6.

58. Bassotti G, Morelli A, Whitehead WE. Abnormal rectosigmoid myoelectric response to eating in pa- 
tients with severe idiopathic constipation (slowtransit type). Dis Colon Rectum 1992;35:753-6.

59. Hanani M, Fellig Y, Udassin R, Freund HR. Agerelated changes in the morphology of the myenteric plexus of the human colon. Auton Neurosci 2004; 113:71-8.

60. Bassotti G, Villanacci V, Maurer CA, et al. The role of glial cells and apoptosis of enteric neurones in the neuropathology of intractable slow transit constipation. Gut 2006;55:41-6.

61. Wedel T, Spiegler J, Soellner S, et al. Enteric nerves and interstitial cells of Cajal are altered in patients with slow-transit constipation and megacolon. Gastroenterology 2002;123:1459-67.

62. Lee JI, Park H, Kamm MA, Talbot IC. Decreased density of interstitial cells of Cajal and neuronal cells in patients with slow-transit constipation and acquired megacolon. J Gastroenterol Hepatol 2005; 20:1292-8.

63. King SK, Sutcliffe JR, Ong SY, et al. Substance P and vasoactive intestinal peptide are reduced in right transverse colon in pediatric slow-transit constipation. Neurogastroenterol Motil 2010 Aug; 22(8):883-92, e234.

64. Sjolund K, Fasth S, Ekman R, et al. Neuropeptides in idiopathic chronic constipation (slow transit constipation). Neurogastroenterol Motil 1997;9:143-50.

65. Liu L, Shang F, Morgan MJ, King DW, Lubowski DZ, Burcher E. Cyclooxygenase-dependent alterations in substance P-mediated contractility and tachykinin NK1 receptor expression in the colonic circular muscle of patients with slow transit constipation. J Pharmacol Exp Ther 2009;329:282-9.

66. Tomita R, Fujisaki S, Ikeda T, Fukuzawa M. Role of nitric oxide in the colon of patients with slowtransit constipation. Dis Colon Rectum 2002;45: 593-600.

67. Crane SJ, Talley NJ. Chronic gastrointestinal symptoms in the elderly. Clin Geriatr Med 2007; 23:721-34.

68. Singh G, Vadhavkar S, Wang H. Complications and comorbidities of constipation in adults. Gastroenterology 2007;132(Suppl 2):A458.

69. Chong PS, Bartolo DC. Hemorrhoids and fissure in ano. Gastroenterol Clin North Am 2008;37:62744.

70. Singh G, Kahler K, Bharathi V. Constipation in adults: complications and comorbidities. Gastroenterology 2005;128(Suppl 2):A154.

71. Mitra D, Davis KL, Baran RW. Healthcare costs and clinical sequelae associated with constipation in a managed care population. Am J Gastroenterol 2007;102:2.

72. Kuncharapu I, Majeroni BA, Johnson DW. Pelvic organ prolapse. Am Fam Physician 2010;81:1111-7.

73. Jeon MJ, Chung SM, Jung HJ, Kim SK, Bai SW. Risk factors for the recurrence of pelvic organ prolapse. Gynecol Obstet Invest 2008;66:268-73.
74. Narayanaswamy S, Walsh M. Calcified fecolith: a rare cause of large bowel obstruction. Emerg Radiol 2007;13:199-200.

75. Nee JM. Colonic obstruction secondary to impaction of a large calcified fecolith: report of a case. Dis Colon Rectum 1983;26:677-8.

76. Maull KI, Kinning WK, Kay S. Stercoral ulceration. Am Surg 1982;48:20-4.

77. Lundy JB, Gadacz TR. Massive fecal impaction presenting with megarectum and perforation of a stercoral ulcer at the rectosigmoid junction. South Med J 2006;99:525-7.

78. Sharma M, Agrawal A. Case report: stercoral sigmoid colonic perforation with fecal peritonitis. Indian J Radiol Imaging 2010;20:126-8.

79. Heffernan C, Pachter HL, Megibow AJ, Macari M. Stercoral colitis leading to fatal peritonitis: CT findings. AJR 2005;184:1189-93.

80. Huang WS, Wang CS, Hsieh CC, Lin PY, Chin CC, Wang JY. Management of patients with stercoral perforation of the sigmoid colon: report of five cases. World J Gastroenterol 2006;12:500-3.

81. Ebell MH, Siwek J, Weiss BD, et al. Strength of recommendation taxonomy (SORT): a patient-centered approach to grading evidence in the medical literature. J Am Board Fam Pract 2004;17:59-67.

82. Muller-Lissner SA, Kamm MA, Scarpignato C, Wald A. Myths and misconceptions about chronic constipation. Am J Gastroenterol 2005;100:232-42.

83. Dukas L, Willett WC, Giovannucci EL. Association between physical activity, fiber intake, and other lifestyle variables and constipation in a study of women. Am J Gastroenterol 2003;98:1790-6.

84. Murakami K, Sasaki S, Okubo H, Takahashi Y, Hosoi Y, Itabashi M. Association between dietary fiber, water and magnesium intake and functional constipation among young Japanese women. Eur J Clin Nutr 2007;61:616-22.

85. Okubo H, Sasaki S, Murakami K, et al. Dietary patterns associated with functional constipation among Japanese women aged 18 to 20 years: a cross-sectional study. J Nutr Sci Vitaminol (Tokyo) 2007;53:232-8.

86. Lindeman RD, Romero LJ, Liang HC, Baumgartner RN, Koehler KM, Garry PJ. Do elderly persons need to be encouraged to drink more fluids? J Gerontol A Biol Sci Med Sci 2000;55:M361-5.

87. Leung FW. Etiologic factors of chronic constipation: review of the scientific evidence. Dig Dis Sci 2007;52:313-6.

88. De Schryver AM, Keulemans YC, Peters HP, et al. Effects of regular physical activity on defecation pattern in middle-aged patients complaining of chronic constipation. Scand J Gastroenterol 2005; 40:422-9.

89. Meshkinpour H, Selod S, Movahedi H, Nami N, James N, Wilson A. Effects of regular exercise in 
management of chronic idiopathic constipation. Dig Dis Sci 1998;43:2379-83.

90. Robson KM, Kiely DK, Lembo T. Development of constipation in nursing home residents. Dis Colon Rectum 2000;43:940-3.

91. Anti M, Pignataro G, Armuzzi A, et al. Water supplementation enhances the effect of high-fiber diet on stool frequency and laxative consumption in adult patients with functional constipation. Hepatogastroenterology 1998;45:727-32.

92. Rao SS, Valestin J, Brown CK, Zimmerman B, Schulze K. Long-term efficacy of biofeedback therapy for dyssynergic defecation: randomized controlled trial. Am J Gastroenterol 2010;105:890-6.

93. Chiarioni G, Whitehead WE, Pezza V, Morelli A, Bassotti G. Biofeedback is superior to laxatives for normal transit constipation due to pelvic floor dyssynergia. Gastroenterology 2006;130:657-64.

94. Simon MA, Bueno AM. Behavioural treatment of the dyssynergic defecation in chronically constipated elderly patients: a randomized controlled trial. Appl Psychophysiol Biofeedback 2009;34:273-7.

95. Amenta M, Cascio MT, Di Fiore P, Venturini I. Diet and chronic constipation: benefits of oral supplementation with symbiotic zir fos (Bifidobacterium longum W11 + FOS Actilight). Acta Biomed 2006;77:157-62.

96. An HM, Baek EH, Jang S, et al. Efficacy of lactic acid bacteria (LAB) supplement in management of constipation among nursing home residents. Nutr J 2010;9:5.

97. Kailasapathy K, Chin J. Survival and therapeutic potential of probiotic organisms with reference to Lactobacillus acidophilus and Bifidobacterium spp. Immunol Cell Biol 2000;78:80-8.

98. McRorie JW, Daggy BP, Morel JG, Diersing PS, Miner PB, Robinson M. Psyllium is superior to docusate sodium for treatment of chronic constipation. Aliment Pharmacol Ther 1998;12:491-7.

99. Cheskin LJ, Kamal N, Crowell MD, Schuster MM, Whitehead WE. Mechanisms of constipation in older persons and effects of fiber compared with placebo. J Am Geriatr Soc 1995;43:666-9.

100. Ashraf W, Park F, Lof J, Quigley EM. Effects of psyllium therapy on stool characteristics, colon transit and anorectal function in chronic idiopathic constipation. Aliment Pharmacol Ther 1995;9:639-47.

101. Tomas-Ridocci M, Anon R, Minguez M, Zaragoza A, Ballester J, Benages A. [The efficacy of Plantago ovata as a regulator of intestinal transit: a doubleblind study compared to placebo]. Rev Esp Enferm Dig 1992;82:17-22.

102. Sturtzel B, Elmadfa I. Intervention with dietary fiber to treat constipation and reduce laxative use in residents of nursing homes. Ann Nutr Metab 2008; 52(Suppl 1):54-6.

103. Sturtzel B, Mikulits C, Gisinger C, Elmadfa I. Use of fiber instead of laxative treatment in a geriatric hospital to improve the wellbeing of seniors. J Nutr Health Aging. 2009;13:136-9.

104. Hamilton JW, Wagner J, Burdick BB, Bass P. Clinical evaluation of methylcellulose as a bulk laxative. Dig Dis Sci 1988;33:993-8.

105. Sakakibara R, Yamaguchi T, Uchiyama T, et al. Calcium polycarbophil improves constipation in primary autonomic failure and multiple system atrophy subjects. Mov Disord 2007;22:1672-3.

106. Dipalma JA, Cleveland MV, McGowan J, Herrera JL. A randomized, multicenter, placebo-controlled trial of polyethylene glycol laxative for chronic treatment of chronic constipation. Am J Gastroenterol 2007;102:1436-41.

107. DiPalma JA, DeRidder PH, Orlando RC, Kolts $\mathrm{BE}$, Cleveland MB. A randomized, placebo-controlled, multicenter study of the safety and efficacy of a new polyethylene glycol laxative. Am J Gastroenterol 2000;95:446-50.

108. Cleveland MV, Flavin DP, Ruben RA, Epstein RM, Clark GE. New polyethylene glycol laxative for treatment of constipation in adults: a randomized, double-blind, placebo-controlled study. South Med J 2001;94:478-81.

109. Tramonte SM, Brand MB, Mulrow CD, Amato MG, O'Keefe ME, Ramirez G. The treatment of chronic constipation in adults: a systematic review. J Gen Intern Med 1997;12:15-24.

110. Petticrew M, Watt I, Sheldon T. Systematic review of the effectiveness of laxatives in the elderly. Health Technol Assess 1997;1:1-52.

111. Lederle FA, Busch DL, Mattox KM, West MJ, Aske DM. Cost-effective treatment of constipation in the elderly: a randomized double-blind comparison of sorbitol and lactulose. Am J Med 1990;89: 597-601.

112. Kutsal E, Aydemir C, Eldes N, et al. Severe hypermagnesemia as a result of excessive cathartic ingestion in a child without renal failure. Pediatr Emerg Care 2007;23:570-2.

113. Kienzle-Horn S, Vix JM, Schuijt C, Peil H, Jordan CC, Kamm MA. Comparison of bisacodyl and sodium picosulphate in the treatment of chronic constipation. Curr Med Res Opin 2007;23:691-9.

114. Kienzle-Horn S, Vix JM, Schuijt C, Peil H, Jordan CC, Kamm MA. Efficacy and safety of bisacodyl in the acute treatment of constipation: a double-blind, randomized, placebo-controlled study. Aliment Pharmacol Ther 2006;23:1479-88.

115. Passmore AP, Davies KW, Flanagan PG, Stoker C, Scott MG. A comparison of Agiolax and lactulose in elderly patients with chronic constipation. Pharmacology 1993;47(Suppl 1):249-52.

116. Passmore AP, Wilson-Davies K, Stoker C, Scott ME. Chronic constipation in long stay elderly patients: a comparison of lactulose and a senna-fibre combination. BMJ 1993;307:769-71. 
117. Marlett JA, Li BU, Patrow CJ, Bass P. Comparative laxation of psyllium with and without senna in an ambulatory constipated population. Am J Gastroenterol 1987;82:333-7.

118. Johanson JF, Morton D, Geenen J, Ueno R. Multicenter, 4-week, double-blind, randomized, placebo-controlled trial of lubiprostone, a locally-acting type-2 chloride channel activator, in patients with chronic constipation. Am J Gastroenterol 2008; 103:170-7.

119. Johanson JF, Ueno R. Lubiprostone, a locally acting chloride channel activator, in adult patients with chronic constipation: a double-blind, placebo-controlled, doseranging study to evaluate efficacy and safety. Aliment Pharmacol Ther 2007;25:1351-61.

120. Barish CF, Drossman D, Johanson JF, Ueno R. Efficacy and safety of lubiprostone in patients with chronic constipation. Dig Dis Sci 2010;55:1090-7.

121. Lin SR, Ke MY, Luo JY, et al. A randomized, double-blind, placebo-controlled trial assessing the efficacy and safety of tegaserod in patients from China with chronic constipation. World J Gastroenterol 2007;13:732-9.

122. Muller-Lissner S, Kamm MA, Musoglu A, Earnest DL, Dunger-Baldauf C, Shetzline MA. Safety, tolerability, and efficacy of tegaserod over 13 months in patients with chronic constipation. Am J Gastroenterol 2006;101:2558-69.

123. Fried M, Johanson JF, Gwee KA, Wagner A, Pecher E, Rueegg P. Efficacy of tegaserod in chronic constipation in men. Am J Gastroenterol 2007;102:362-70.

124. Quigley EM, Wald A, Fidelholtz J, Boivin M, Pecher E, Earnest D. Safety and tolerability of tegaserod in patients with chronic constipation: pooled data from two phase III studies. Clin Gastroenterol Hepatol 2006;4:605-13.

125. Brandt LJ. The FDA's decision-making process: isn't it time to temper the principle of protective paternalism? Am J Gastroenterol 2008;103:1226-7.

126. Schiller LR, Johnson DA. Balancing drug risk and benefit: toward refining the process of FDA decisions affecting patient care. Am J Gastroenterol 2008;103:815-9.

127. Chey WD, Pare P, Viegas A, Ligozio G, Shetzline MA. Tegaserod for female patients suffering from IBS with mixed bowel habits or constipation: a randomized controlled trial. Am J Gastroenterol 2008;103:1217-25.

128. Loughlin J, Quinn S, Rivero E, et al. Tegaserod and the risk of cardiovascular ischemic events: an observational cohort study. J Cardiovasc Pharmacol Ther 2010;15:151-7.

129. Anderson JL, May HT, Bair TL, Muhlestein JB, Horne BD, Carlquist JF. Lack of association of tegaserod with adverse cardiovascular outcomes in a matched case-control study. J Cardiovasc Pharmacol Ther 2009;14:170-5.
130. Camilleri M, Beyens G, Kerstens R, Robinson P, Vandeplassche L. Safety assessment of prucalopride in elderly patients with constipation: a doubleblind, placebo-controlled study. Neurogastroenterol Motil 2009;21(12):1256-e117.

131. Camilleri M, Kerstens R, Rykx A, Vandeplassche L. A placebo-controlled trial of prucalopride for severe chronic constipation. N Engl J Med 2008;358: 2344-54.

132. Quigley EM, Vandeplassche L, Kerstens R, Ausma J. Clinical trial: the efficacy, impact on quality of life, and safety and tolerability of prucalopride in severe chronic constipation: a 12-week, randomized, double-blind, placebo-controlled study. Aliment Pharmacol Ther 2009;29:315-28.

133. Coremans G, Kerstens R, De Pauw M, Stevens M. Prucalopride is effective in patients with severe chronic constipation in whom laxatives fail to provide adequate relief: results of a double-blind, placebo-controlled clinical trial. Digestion 2003;67: 82-89.

134. Dubois D, Gilet H, Viala-Danten M, Tack J. Psychometric performance and clinical meaningfulness of the Patient Assessment of Constipation-Quality of Life questionnaire in prucalopride (RESOLOR) trials for chronic constipation. Neurogastroenterol Motil 2010;22:e54-63.

135. Frampton JE. Prucalopride. Drugs 2009;69:2463-76.

136. Jia G, Meng MB, Huang ZW, et al. Treatment of functional constipation with the Yun-chang capsule: a double-blind, randomized, placebo-controlled, dose-escalation trial. J Gastroenterol Hepatol 2010;25:487-93.

137. Cheng CW, Bian ZX, Zhu LX, Wu JC, Sung JJ. Efficacy of a Chinese herbal proprietary medicine (Hemp Seed Pill) for functional constipation. Am J Gastroenterol 2011;106:120-9.

138. Lin LW, Fu YT, Dunning T, et al. Efficacy of traditional Chinese medicine for the management of constipation: a systematic review. J Altern Complement Med 2009;15:1335-46.

139. Arebi N, Kalli T, Howson W, Clark S, Norton C. Systematic review of abdominal surgery for chronic idiopathic constipation. Colorectal Dis Oct 22, 2010 [Epub ahead of print].

140. Faried M, El Nakeeb A, Youssef M, Omar W, El Monem HA. Comparative study between surgical and non-surgical treatment of anismus in patients with symptoms of obstructed defecation: a prospective randomized study. J Gastrointest Surg 2010;14: 1235-43.

141. Farid M, Youssef T, Mahdy T, et al. Comparative study between botulinum toxin injection and partial division of puborectalis for treating anismus. Int $\mathrm{J}$ Colorectal Dis 2009;24:327-34.

142. Annells M, Koch T. Constipation and the preached trio: diet, fluid intake, exercise. Int J Nurs Stud 2003;40:843-52. 
143. Zanetti G, Marchiori E, Gasparetto TD, Escuissato DL, Soares Souza A Jr. Lipoid pneumonia in children following aspiration of mineral oil used in the treatment of constipation: high-resolution CT findings in 17 patients. Pediatr Radiol 2007;37:1135-9.

144. Guntupalli KK, Francis PB. Unilateral lung infiltrate: lipoid pneumonia. Eur Respir J 1991;4:125-7.

145. Staiano A. Use of polyethylene glycol solution in functional and organic constipation in children. Ital J Gastroenterol Hepatol 1999;31(Suppl 3):S260-3.

146. Corazziari E, Badiali D, Bazzocchi G, et al. Long term efficacy, safety, and tolerabilitity of low daily doses of isosmotic polyethylene glycol electrolyte balanced solution (PMF-100) in the treatment of functional chronic constipation. Gut 2000;46:522-6.

147. Badiali D, Corazziari E. Use of low dose polyethylene glycol solutions in the treatment of functional constipation. Ital J Gastroenterol Hepatol 1999; 31(Suppl 3):S245-8.

148. Staumont G, Frexinos J, Fioramonti J, Bueno L. Sennosides and human colonic motility. Pharmacology 1988;36(Suppl 1):49-56.

149. Wilkins JL, Hardcastle JD. The mechanism by which senna glycosides and related compounds stimulate peristalsis in the human colon. Br J Surg 1970;57:864.

150. Ewe K, Ueberschaer B, Press AG. Influence of senna, fibre, and fibre + senna on colonic transit in loperamide-induced constipation. Pharmacology 1993;47(Suppl 1):242-8.

151. Manabe N, Cremonini F, Camilleri M, Sandborn WJ, Burton DD. Effects of bisacodyl on ascending colon emptying and overall colonic transit in healthy volunteers. Aliment Pharmacol Ther 2009;30:930-6.

152. Lubiprostone: RU 0211, SPI 0211. Drugs R D 2005;6:245-8.

153. Hussar DA. New drugs: lubiprostone, ranolazine, and anidulafungin. J Am Pharm Assoc 2006;46:411-4.

154. Tuteja AK, Rao SS. Lubiprostone for constipation and irritable bowel syndrome with constipation. Expert Rev Gastroenterol Hepatol 2008;2:727-33.

155. Kim HS. 5-Hydroxytryptamine4 receptor agonists and colonic motility. J Smooth Muscle Res 2009;45:25-9.

156. Grider JR, Foxx-Orenstein AE, Jin JG. 5-Hydroxytryptamine4 receptor agonists initiate the peristaltic reflex in human, rat, and guinea pig intestine. Gastroenterology 1998;115:370-80.

157. Tack J. Prucalopride: a new drug for the treatment of chronic constipation. Expert Rev Gastroenterol Hepatol 2009;3:337-43.

158. Johnston JM, Kurtz CB, Drossman DA, et al. Pilot study on the effect of linaclotide in patients with chronic constipation. Am J Gastroenterol 2009; 104:125-32.

159. Lembo AJ, Kurtz CB, Macdougall JE, et al. Efficacy of linaclotide for patients with chronic constipation. Gastroenterology 2010;138:886-95.
160. Khalif IL, Quigley EM, Konovitch EA, Maximova ID. Alterations in the colonic flora and intestinal permeability and evidence of immune activation in chronic constipation. Dig Liver Dis 2005;37:838-49.

161. Borody TJ, Warren EF, Leis SM, Surace R, Ashman $\mathrm{O}$, Siarakas S. Bacteriotherapy using fecal flora: toying with human motions. J Clin Gastroenterol 2004;38:475-83.

162. American College of Gastroenterology Chronic Constipation Task Force. An evidence-based approach to the management of chronic constipation in North America. Am J Gastroenterol 2005; 100(Suppl 1):S1-4.

163. Locke GR 3rd, Pemberton JH, Phillips SF. American Gastroenterological Association Medical Position Statement: guidelines on constipation. Gastroenterology 2000;119:1761-6.

164. Southwell BR, Clarke MC, Sutcliffe J, Hutson JM. Colonic transit studies: normal values for adults and children with comparison of radiological and scintigraphic methods. Pediatr Surg Int 2009;25:559-72.

165. Lundin E, Karlbom U, Westlin JE, et al. Scintigraphic assessment of slow transit constipation with special reference to right- or left-sided colonic delay. Colorectal Dis 2004;6:499-505.

166. Lembo A, Camilleri M. Chronic constipation. N Engl J Med 2003;349:1360-8.

167. Elshazly WG, El Nekady Ael A, Hassan H. Role of dynamic magnetic resonance imaging in management of obstructed defecation case series. Int J Surg 2010;8:274-82.

168. Li D, Browne LW, Ladabaum U. Melanosis coli. Clin Gastroenterol Hepatol 2009;7:A20.

169. Wittoesch JH, Jackman RJ, Mc DJ. Melanosis coli: general review and a study of 887 cases. Dis Colon Rectum 1958;1:172-80.

170. Villanacci V, Bassotti G, Cathomas G, et al. Is pseudomelanosis coli a marker of colonic neuropathy in severely constipated patients? Histopathology 2006;49:132-7.

171. Walker NI, Bennett RE, Axelsen RA. Melanosis coli: a consequence of anthraquinone-induced apoptosis of colonic epithelial cells. Am J Pathol 1988; 131:465-76.

172. Orlando FA, Tan D, Baltodano JD, et al. Aberrant crypt foci as precursors in colorectal cancer progression. J Surg Oncol 2008;98:207-13.

173. Bird RP, McLellan EA, Bruce WR. Aberrant crypts, putative precancerous lesions, in the study of the role of diet in the aetiology of colon cancer. Cancer Surv 1989;8:189-200.

174. Magnuson BA, Carr I, Bird RP. Ability of aberrant crypt foci characteristics to predict colonic tumor incidence in rats fed cholic acid. Cancer Res 1993; 53:4499-504.

175. Pretlow TP, O'Riordan MA, Pretlow TG, Stellato TA. Aberrant crypts in human colonic mucosa: pu- 
tative preneoplastic lesions. J Cell Biochem Suppl 1992;16G:55-62.

176. Figueiredo IN, Figueiredo PN, Stadler G, Ghattas $\mathrm{O}$, Araujo A. Variational image segmentation for endoscopic human colonic aberrant crypt foci. IEEE Trans Med Imaging 2010;29:998-1011.

177. Tudek B, Bird RP, Bruce WR. Foci of aberrant crypts in the colons of mice and rats exposed to carcinogens associated with foods. Cancer Res 1989;49:1236-40.

178. Mascolo N, Mereto E, Borrelli F, et al. Does senna extract promote growth of aberrant crypt foci and malignant tumors in rat colon? Dig Dis Sci 1999; 44:2226-30.

179. Mereto E, Ghia M, Brambilla G. Evaluation of the potential carcinogenic activity of Senna and Cascara glycosides for the rat colon. Cancer Lett 1996; 101:79-83

180. Nascimbeni R, Donato F, Ghirardi M, Mariani P, Villanacci V, Salerni B. Constipation, anthranoid laxatives, melanosis coli, and colon cancer: a risk assessment using aberrant crypt foci. Cancer Epidemiol Biomarkers Prev 2002;11:753-7.

181. Borrelli F, Mereto E, Capasso F, et al. Effect of bisacodyl and cascara on growth of aberrant crypt foci and malignant tumors in the rat colon. Life Sci 2001;69:1871-7.

182. Borrelli F, Capasso R, Aviello G, et al. Senna and the formation of aberrant crypt foci and tumors in rats treated with azoxymethane. Phytomedicine 2005;12:501-5.
183. van Gorkom BA, Karrenbeld A, van Der Sluis T, Koudstaal J, de Vries EG, Kleibeuker JH. Influence of a highly purified senna extract on colonic epithelium. Digestion 2000;61:113-20.

184. Siegers CP, von Hertzberg-Lottin E, Otte M, Schneider B. Anthranoid laxative abuse: a risk for colorectal cancer? Gut 1993;34:1099-101.

185. Nusko G, Schneider B, Muller G, Kusche J, Hahn EG. Retrospective study on laxative use and melanosis coli as risk factors for colorectal neoplasma. Pharmacology 1993;47(Suppl 1):234-41.

186. Dukas L, Willett WC, Colditz GA, Fuchs CS, Rosner B, Giovannucci EL. Prospective study of bowel movement, laxative use, and risk of colorectal cancer among women. Am J Epidemiol 2000;151: 958-64.

187. Jacobs EJ, White E. Constipation, laxative use, and colon cancer among middle-aged adults. Epidemiology 1998;9:385-91.

188. Nusko G, Schneider B, Schneider I, Wittekind C, Hahn EG. Anthranoid laxative use is not a risk factor for colorectal neoplasia: results of a prospective case control study. Gut 2000;46:651-55.

189. Nusko G, Schneider B, Ernst H, Wittekind C, Hahn EG. Melanosis coli: a harmless pigmentation or a precancerous condition? Z Gastroenterol 1997; 35:313-8.

190. Morales MA, Hernandez D, Bustamante S, Bachiller I, Rojas A. Is senna laxative use associated to cathartic colon, genotoxicity, or carcinogenicity? J Toxicol 2009;2009:287247. 